\title{
EXISTENCE AND UNIQUENESS OF POSITIVE SOLUTIONS TO A COUPLED SYSTEM OF NONLINEAR FRACTIONAL ORDER DIFFERENTIAL EQUATIONS WITH ANTI PERIODIC BOUNDARY CONDITIONS
}

\author{
KAMAL ShaH AND RaHmat Ali Khan
}

Abstract. In this article, we study sufficient conditions for existence and uniqueness of positive solutions to the following coupled system of fractional order differential equations with antiperiodic boundary conditions

$$
\left\{\begin{array}{l}
{ }^{c} D^{\alpha} u(t)+f\left(t, v(t),{ }^{c} D^{\alpha-1} v(t)\right)=0,{ }^{c} D^{\beta} v(t)+g\left(t, u(t),{ }^{c} D^{\beta-1} u(t)\right)=0, \quad 0<t<1, \\
u(0)=-u(1), v(0)=-v(1), D^{p} u(0)=-D^{p} u(1), D^{q} v(0)=-D^{q} v(1),
\end{array}\right.
$$

where $1<\alpha, \beta \leqslant 2, \alpha-p \geqslant 1, \beta-q \geqslant 1$ and $0<p, q<1, f, g:[0,1] \times \mathbb{R} \times \mathbb{R} \rightarrow \mathbb{R}$ are continuous functions and $D$ stands for Caputo derivative. We use Banach and Schauder fixed point theorems to develop sufficient conditions for existence and uniqueness of positive solutions. We also study sufficient conditions for existence of multiple positive solutions and conditions for non existence of solutions. We provide several examples to show the applicability of our results. We also link our analysis for the problem to equivalent integral equations.

Mathematics subject classification (2010): 47J05, 92D25, 34A08, 34A34, 34K15.

Keywords and phrases: Coupled system, Fractional differential equations, Anti-periodic boundary conditions, Fixed point theorems.

\section{REFERENCES}

[1] V. LAKShMiKantham AND A. VATSALA,General uniqueness and monotone iterative technique for fractional differential equation, Applied Mathematics Letter., 21, (2008), 828-834.

[2] V. LAKShmiKantham AND S. LeEL, Naguma-type uniqueness result for fractional differential equations,Nonlinear Analysis., 71, (2009), 2886-2889.

[3] M. FENG AND W. GE, Existence result for a class of nth order m-point boundary value problem in Banach space, Applied Mathematics Letter., 22, (2009), 1303-1308.

[4] C. Goodrich, Existence of a positive solution to a class of Fractional differential equations, Computer Mathematics with Appllication., 59, (2010), 3889-3999.

[5] Z. Bai, On positive solution of a non local fractional boundary value problem, Nonlinear Analysis, 72, (2010), 916-924.

[6] B. AHMAD AND J. NiETo,Existence of solutions for non local boundary value problems of higher order non linear fractional differential equations, Abstract and Applied Analysis, (2009), Article ID 494720.

[7] B. AHMAD AND J.J. NIETO, Existence and approximation of solution for a class of non-linear impulsive fractional differential equation with anti-periodic boundary conditions, Nonlinear Analysis, 69, (2008, 3291-3298.

[8] M. Benchohra, N. HAMidi AND J. Henderson, Existence and uniqueness of solution for fractional differential equations with Anti-periodic boundary condition, Numerical Functional Analysis and Optimization, 34,4(2013), 404-414. 
[9] M. BEnchohra, J. R. GRAEF AND S. HAMANi, Existence result for boundary value problem with non-linear fractional differential equations, Applied Analysis, 87,(2008), 851-863.

[10] B. AHMAD AND V. OTERO EsPINAR, Existence of solution for fractional differential inclusions with anti-periodic boundary conditions Boundary valaue problems, (2009), Art. 6259347,pp 11.

[11] X. SU, Boundary value problem for a coupled system of non linear fractional differential equations, Applied Mathematical Letter, 22, (2009), 64-69.

[12] B. AhmAD AND J. J. NiETo, Existence result for a coupled system of non linear fractional differential equations with three point boundary conditions, Computer Mathematics with Appllication, 58, (2009), $1838-1843$.

[13] J. Wang, M. Xiang And Z. LiU, Positive solution to a non zero boundary value problem for a coupled system of non linear fractional differential equations, International Journal of Differential Equations, 12,(2010), Article ID 186928.

[14] I. Podlubny, Fractional differential equations, Academic press, New York 1993.

[15] A.A. Kilbas, H. SRivastava And J. TRujillo, Theory and application of fractional differential equations, North Holland Mathematical Studies., 204, Elseveir, Amsterdam, 2006.

[16] M. Feng, X. Zhang AND W.Ge, New existence results for higher-order nonlinear fractional differential equation with intigral boundary conditions, Boundary Value Problems, 20,(2011), ArticleID720702.

[17] E. ZEIDLER, Non linear fractional analysis and its application-I Fixed-point Theorem, Springer, New York, USA 1986.

[18] M. REHMAN AND R. A. KHAN, A note on boundary value problems for a coupled system of fractional differential equations, computer Mathematics with Appllication, 61, (2011), 2630-2637.

[19] B. AhmAD, AND S. K. NTOUYAS, A fully Hadamard type integral boundary value problem of a coupled system of fractional differential equations, Fractional Calculus and Applied Analysis, 17, 2(2014), 348-360.

[20] Y. LiU AND B. Ahmad, A Study of Impulsive Multiterm Fractional Differential Equations with Single and Multiple Base Points and Applications, Scientific World Journal, (2014), 1-28.

[21] Y. LiU,Solvability of multi-point boundary value problems for multiple term Riemann-Liouville fractional differential equations, Computet Mathematics with Appllications, 64, (2012), 413-431.

[22] Y. LIU,Positive solutions for singular FDES,U.P.B.Sci. Series A,. 73,(2011), 89-100.

[23] Y. LIU AND X. LIU,Existence of solutions of resonant boundary value problems for fractional differential equations, Differential Equations and Control Process, 3,(2012), 70-90.

[24] Y. LIU, T. HE AND H. SHI,Three positive solutions of Sturm-Liouville boundary value problems for fractional differential equations, Differ. Equ. Appl., 5, (2013), 127-152, doi:10.7153/dea-05-09. 